\title{
PENELITIAN TINDAKAN KELAS MODEL GROUP TO GROUP EXCHANGE
}

\author{
Tanti Rahmawati ${ }^{1)}$, Fitri Nurlaili ${ }^{2)}$ \\ Universitas Banten Jaya \\ Serang,Indonesia \\ tantira28@gmail.com ${ }^{1)}$, fitrinurlaili@unbaja.ac.id ${ }^{2)}$
}

\begin{abstract}
This research aims to know the application of cooperative learning model of type group to group exchange on subjects of financial accounting as well as knowing the results of learning students after teaching and learning activities using the learning model Group to group exchange.This research used classroom action research with two cycles and each cycles consist of four steps : planning, action, observing and reflection. The results of this research show that the model of the learning group to group exchange can improve student learning activities. The results of the observation activities of students in cycle 1 of $70 \%$ and cycle 2 of 90\%. In addition, the results of this research also shows that the model of the learning group to group exchange can also improve student learning outcomes. In cycle 1, of 31 students in attendance who managed to reach the KKM of $61.29 \%$, with average result 80,74 while on cycle 2 of 33 students in attendance who managed to reach the KKM of 89,19\%.with average result 84,61 .
\end{abstract}

Keywords : Learning Model, Group to Group Exchange, Learning Achievment

\section{PENDAHULUAN}

Pendidikan merupakan salah satu pilar utama dalam mengantisipasi masa depan, karena pendidikan selalu diorientasikan pada penyiapan peserta didik untuk berperan di masa yang akan datang. Pendidikan pada dasarnya adalah proses untuk membantu manusia dalam mengembangkan potensi dirinya. Proses ini dilaksanakan semata-mata dengan tujuan untuk mencerdaskan manusia memanusiakan manusia.
Dalam proses pendidikan, PBM (Proses Belajar Mengajar) merupakan aktivitas paling penting, karena melalui proses inilah disiapkan untuk berperan dimasa depan dalam bentuk perubahan perilaku manusia. PBM, dalam prosesnya terdapat dua posisi subjek, yaitu guru sebagai pihak yang mengajar dan siswa sebagai pihak yang belajar. Hal ini mengimplikasikan bahwa PBM merupakan suatu proses interaksi antara guru dan siswa yang didasari oleh hubungan yang bersifat mendidik dalam rangka pencapaian tujuan. 
Berdasarkan hasil penelitian awal yang dilakukan pada siswa jurusan akuntansi di SMKN 7 Kota Serang, dapat diketahui masalah yang terjadi adalah siswa mengalami permasalahan dalam belajar, antara lain siswa kurang memiliki minat untuk belajar akuntansi, pelajaran akuntansi yang dirasa sulit, dan juga siswa kurang memahami materi dalam proses belajar-mengajar sehingga membuat siswa membutuhkan waktu lama dalam mengerjakan soal akuntansi, yang akhirnya juga berdampak pada nilai yang diperoleh siswa menjadi rendah.

Banyaknya siswa yang mengalami masalah belajar dan nilai rendah pada pelajaran akuntansi didukung hasil wawancara dengan guru akuntansi SMKN 7 Kota Serang. Siswa dinilai kurang mampu dalam menyelesaikan masalah akuntansi, kurangnya minat dan keaktifan belajar siswa di kelas, serta hasil belajar siswa yang cenderung rendah.

Belajar pada hakikatnya adalah proses interaksi terhadap semua situasi yang ada di sekitar individu. Belajar dapat dipandang sebagai proses yang diarahkan kepada tujuan dan proses berbuat melalui berbagai pengalaman. Menurut Sudjana dalam Rusman
(2011:1), "belajar juga merupakan proses melihat, mengamati, dan memahami sesuatu".

Gagne dalam Suprijono (2015:2) menyatakan bahwa "belajar adalah perubahan disposisi atau kemampuan yang dicapai seseorang melalui aktivitas. Perubahan disposisi tersebut bukan diperoleh langsung dari proses pertumbuhan seseorang secara alamiah".

Berdasarkan definisi tersebut, dapat dikatakan bahwa belajar adalah proses dimana individu melalui pengalamannya berinteraksi dengan lingkungan menyebabkan terjadinya perubahan tingkah laku yang relatif permanen.

Penggunaan model pembelajaran yang inovatif, progresif, dan kontekstual merupakan konsep belajar yang mampu membantu guru mengaitkan antara materi yang diajarkan dengan situasi dunia nyata siswa, dan mendorong siswa membuat hubungan antara pengetahuan yang dimilikinya dan penerapannya dalam kehidupan mereka sebagai anggota keluarga dan masyarakat. Dengan konsep itu, hasil pembelajaran diharapkan lebih bermakna bagi siswa.

Cooperative learning adalah suatu model pembelajaran yang berpusat pada 
siswa, dimana siswa dibagi ke dalam beberapa kelompok dan saling bekerja sama untuk mengatasi suatu permasalahan. Slavin dalam Isjoni (2016:15) mengemukakan "In cooperative learning methods, student work together in four member teams to master material initially presented by the teacher". Dari uraian tersebut dapat dikemukakan bahwa cooperative learning adalah suatu model pembelajaran dimana sistem belajar dan bekerja dalam kelompok-kelompok kecil yang berjumlah 4-6 orang secara kolaboratif sehingga dapat merangsang siswa lebih bergairah dalam belajar.

Salah satu model pembelajaran cooperative learning yang dapat diterapkan untuk menumbuhkan kreatifitas siswa adalah model pembelajaran kooperatif tipe Group to Group Exchange.

Menurut Silberman (2013), Group to group exchange adalah salah satu model belajar aktif yang menuntut siswa untuk berpikir tentang apa yang dipelajari, berkesempatan untuk berdiskusi dengan teman, bertanya dan membagi pengetahuan yang diperoleh kepada yang lainnya. Group to group exchange memberi kesempatan kepada siswa untuk bertindak sebagai guru bagi siswa lainnya.

Menurut Silberman

Langkah-langkah model pembelajaran kooperatif tipe Group to Group Exchange adalah sebagai berikut :

1) Guru memilih topik yang mencakup gagasan, kejadian, pendapat, atau konsep yang berbeda. Dalam pembelajaran, topik yang dipilih mencakup konsep yang berbeda.

2) Guru membagi siswa menjadi beberapa kelompok sesuai dengan jumlah tugas yang diberikan. Tugas yang diberikan pada tiap kelompok berbeda.

3) Guru memberi waktu yang mencukupi kepada tiap kelompok untuk menyiapkan cara mereka menyajikan topic yang ditugaskan kepada kelompok mereka masingmasing, untuk nanti dipresentasikan kepada kelompok lain.

4) Bila tahap persiapan sudah selesai, guru meminta kelompok untuk memilih juru bicara. Undang tiap juru bicara untuk memberikan presentasi kepada kelompok lain.

5) Setelah presentasi singkat, guru mendorong siswa untuk 
mengajukan pertanyaan atau menawarkan pendapat mereka sendiri kepada penyaji materi (juru bicara). Beri kesempatan anggota lain dari kelompok juru bicara untuk memberikan tanggapan.Lanjutkan presentasi kelompok lain agar tiap kelompok berkesempatan memberikan informasi dan menjawab serta menanggapi pertanyaan dan komentar kelompok lainnya. Perbandingkan dan perbedakan pendapat dan informasi yang dipertukarkan.

6) Variasi dapat dilakukan dengan meminta setiap kelompok melakukan diskusi sebelum presentasi dan menggunakan diskusi bersama untuk masingmasing presentasi sub-kelompok.

Menurut Silberman (2013) model kooperatif tipe Group to group exchange memiliki kelebihan dan kekurangan sebagai berikut :

1) Siswa menjadi lebih aktif karena siswa diberikan kesempatan untuk berdiskusi dengan kelompok, bertanya dan membagi pengetahuan yang diperoleh kepada yang lainnya melalui presentasi dan tanya jawab antar kelompok.

2) Siswa lebih memahami materi yang diberikan karena dipelajari lebih dalam dan sederhana dengan anggota kelompoknya.

3) Siswa lebih memahami materi karena dijelaskan oleh teman sebayanya dengan cara mereka masing-masing lewat presentasi kelompok.

4) Siswa lebih menguasai materi karena mampu mengajarkan kepada siswa lain saat presentasi

5) Meningkatkan kerjasama kelompok Sedangkan kekurangan dari metode ini adalah :

1) Waktu yang dibutuhkan dalam pembelajaran relatif lama.

2) Membutuhkan keberanian dan kesiapan siswa untuk menjadi juru bicara.

\section{METODE PENELITIAN}

Penelitian ini dilakukan di Sekolah Menengah Kejuruan (SMK) Negeri 7 Kota Serang yang beralamat di Jl. Raya Bangdes kampong baru Pakupatan, Kel Panancangan Kec. Cipocok Jaya Kota Serang.

Dalam penelitian ini peneliti berperan dalam perencanaan kegiatan pembelajaran dan berkolaborasi dengan 
guru mata pelajaran akuntansi keuangan.

Peneliti juga ikut serta dalam proses pembelajaran menggunakan model pembelajaran group to group exchange ini.

Penelitian ini menggunakan desain penelitian tindakan kelas. Menurut Arikunto (2013) pelaksanaan PTK terdiri dari empat tahap yaitu : (1) Perencanaan, (2) Pelaksanaan,

Observasi (4) Refleksi.

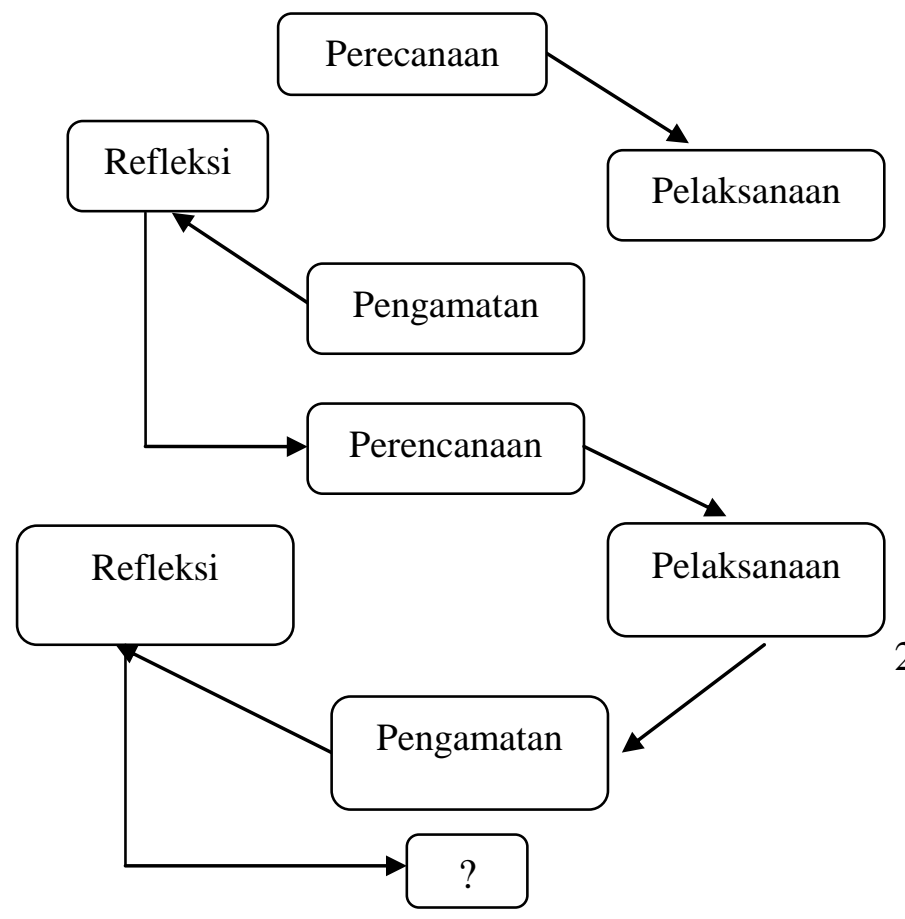

Gb.1 Alur Penelitian Tindakan Kelas Arikunto (2014:16)

Prosedur dalam penelitian ini terdiri dari tahapan yang ada dalam setiap siklus yang terdiri dari beberapa tahap kegiatan, yaitu :
1. Tahap Perencanaan

Dalam tahap ini peneliti menjelaskan tentang apa, mengapa, kapan, dimana, oleh siapa, dan bagaimana tindakan tersebut dilakukan. perencanaan siklus pertama didasarkan pada identifikasi masalah yang dilakukan pada tahap pra PTK.

Rencana tindakan ini sering dikenal dengan planning, kegiatan pokok yang dilakukan adalah:

a. Menyusun rencana pelaksanaan Pembelajaran berdasarkan silabus yang telah dibuat dengan model pembelajaran Group to group exchange

b. Merancang pengorganisasian kelas.

c. Menyusun dan mempersiapkan instrumen.

2. Pelaksanaan

Kegiatan pokok dalam pelaksanaan adalah :

a. Melaksanakan sesuai dengan perencanaan.

b. Selama berlangsung peneliti melakukan observasi secara teliti dan rinci sesuai pedoman dan instrument yang telah disiapkan untuk mendapatkan hasil secara detail baik berupa 
perubahan positif dan negatif, peningkatan pada motivasi, sikap, nilai, dan kemampuan tanpa ada yang terlewati. Hal ini tentu sudah dirancang dalam kegiatan KBM dalam RPP.

c. Selama observasi berlangsung juga akan terjadi satu interprestasi terhadap tindakan yang dilakukan dan merekam proses pembelajaran berlangsung.

d. Selanjutnya dapat dilakukan analisis data dan evaluasi

\section{Observasi}

Proses ini dilakukan bersamaan dengan pelaksanaan tindakan. peneliti mengamati dan mencatat semua hal yang terjadi selama aktivitas pembelajaran. Peneliti juga mencari kelebihan dan kekurangan dalam penerapan model pembelajaran group to group exchange ini dalam memperoleh yang dibutuhkan.

4. Refleksi

Refleksi dilakukan dengan menyusun laporan dari semua kegiatan yang telah dilaksanakan selama penelitian. Sehingga peneliti dapat menentukan hal-hal yang akan dilakukan untuk perbaikan. Keputusan untuk menghentikan atau melanjutkan siklus ditentukan berdasarkan hasil yang diperoleh. Siklus dihentikan jika pembelajaran yang dilakukan sudah sesuai dengan rencana.

Data dikumpulkan dengan cara :

1. Observasi

2. Tes

3. Wawancara

4. Dokumentasi

Instrument pengumpulan data berupa :

1. Lembar Observasi

2. Lembar tes/evaluasi

3. Pedoman Wawancara

4. Dokumentasi

Adapun Indikator Keberhasilan yang diharapkan dalam penelitian ini adalah hasil belajar siswa pada mata pelajaran akuntansi keuangan dapat meningkat. Ditunjukkan dengan pencapaian hasil belajar pada siswa dengan KKM yang telah ditetapkan sekolah.

Sebagai tolak ukur keberhasilan bagi siswa, yaitu dapat meningkatkan hasil belajar siswa dalam mata pelajaran akuntansi dengan menggunakan metode group to group exchange, diantaranya : 
a. Setelah menggunakan model pembelajaran group to group exchange Aktivitas siswa dalam proses pembelajaran mencapai 90\% dari jumlah keseluruhan siswa.

b. Hasil belajar siswa mencapai presentase ketuntasan belajar 85\% dari jumlah keseluruhan siswa.

Data yang diperoleh kemudian dianalisis dengan mengolah hasil belajar dan mengolah hasil observasi menggunakan teknik deskriptif.

Dalam penelitian ini peneliti melakukan kolaborasi bersama guru mata pelajaran akuntansi keuangan kelas XI SMKN 7 Kota Serang.

1. Peneliti bersama guru melakukan diskusi dan wawancara terkait dengan permasalahan yang melatarbelakangi penelitian ini.

2. Peneliti bersama guru melakukan diskusi terkait dengan rencana pelaksanaan pembelajaran (RPP) dan materi pelajaran akuntansi.

3. Peneliti menyusun rencana pelaksanaan pembelajaran (RPP) bersama guru.
4. Peneliti dan guru bersama-sama mengimplementasikan RPP yang telah dibuat.

\section{HASIL PENELITIAN DAN PEMBAHASAN}

Penelitian dilakukan sebanyak dua siklus. Penggunaan dua siklus dilakukan karena pada siklus I ketercapaian indikator keberhasilan belum optimal, sehingga penelitian dilanjutkan ke siklus 2. Pada siklus 2, indikator keberhasilan dapat tercapai sehingga penelitian dihentikan pada akhir siklus 2 .

Pada tahap perencanaan siklus 1 , sebelum dilaksanakannya penelitian, peneliti mengadakan pertemuan dengan guru mata pelajaran akuntansi. Pada pertemuan ini, peneliti dan guru berdiskusi bersama, menyusun Rencana Pelaksanaan Pembelajaran (RPP), menyiapkan materi pembelajaran dan menyiapkan instrument penelitian berupa tes dan non tes. Instrumen tes digunakan untuk mengetahui hasil belajar siswa dengan dilihat dari hasil evaluasi, sedangkan instrument non tes digunakan untuk mengetahui keaktifan siswa selama kegiatan pembelajaran berlangsung. 
Dalam kegiatan pelaksanaan pada siklus1 peneliti melaksanakan pembelajaran menggunakan model pembelajaran group to group exchange pada mata pelajaran akuntansi keuangan. Pelaksanaan tindakan merupakan implementasi dari hasil rencana tindakan yang telah disusun pada tahap perencanaan. Kegiatan pelakasanaan akan dilaksanakan sesuai dengan perencanaan pembelajaran yang telah disusun. Materi pembelajaran diberikan dalam tiga kali pertemuan dengan alokasi waktu masingmasing 3 kali pertemuan, pada setiap pertemuan terdiri dari beberapa tahap yaitu pendahuluan, inti, dan penutup.

Hasil pengamatan terhadap pelaksanaan proses pembelajaran akuntansi keuangan, diperoleh gambaran aktivitas dan hasil belajar siswa selama kegiatan belajar sebagai berikut :

1. Berdasarkan hasil pengamatan aktivitas siswa, dari 31 siswa yang hadir pada siklus 1, aktivitas siswa yang berhasil dicapai sebesar $70 \%$ yaitu berada pada kriteria C (Cukup).

2. Dari jumlah keseluruhan 37 siswa, yang tuntas dalam mata pelajaran akuntansi ini ada 19 siswa, yang tidak tuntas sebanyak 12 siswa, sisanya 5 siswa tidak hadir dalam proses pembelajaran siklus 1 ini. dapat disimpulkan sebanyak $61,29 \%$ siswa sudah berhasil mencapai KKM. Dengan nilai rata-rata 80,74

Berdasarkan hasil yang diperoleh pada siklus I, terdapat beberapa refleksi yang dilakukan guru bersama peneliti untuk dijadikan feedback pada siklus berikutnya, diantaranya :

1. Guru kurang memotivasi atau melakukan pendekatan kepadasiswa yang lambat dalam memahami pelajaran dan siswa yang kurang bersosialisasi kepada temantemannya. Sehingga merekamasih mengandalkan teman dekatnya dan belum bisa ikut mengungkapkan pendapatnya dalam mengerjakan tugas kelompok.

2. Guru belum sepenuhnya menjangkau siswa pada saat proses diskusi berlangsung.

3. Guru kurang memberikan penghargaan kepada siswa yang mampu menyelesaikan tugas dengan benar.

4. Siswa masih belum sungguhsungguh dalam mengikuti pelajaran dikarenakan masih bingung dalam memahami materi yang dipelajari. 
5. Masih ada siswa yang merasa malas dan bingung untuk bergabung dengan kelompoknya.

6. Siswa baru akan ikut serta dalamdiskusi dan mengerjakan tugasnya apabila guru melakukan pendekatan. Oleh karena itu peran guru sebagai fasilitator sangatlah penting dalam kegiatan belajar mengajar.

6. Siswa belum berani mengungkapkan pendapatnya dalam menjelaskan kembali pada teman-temannya.

Indikator penelitian pada siklus

I belum terpenuhi oleh karena itu penelitian dilanjutkan pada siklus 2 . Pada siklus 2 ini, kelemahan-kelemahan yang terjadi dalam siklus 1 akan diperbaiki di siklus 2 .

Siklus 2 dilaksanakan mengikuti pola penelitian tindakan kelas yang sama, yaitu perencanaan, pelaksanaan, observasi dan refleksi. Perencanaan disusun dengan memperhatikan refleksi siklus 1 . Pelaksanaan siklus 2 juga dilaksanakan dalam 3 kali pertemuan menggunakan group to group exchange. Berdasarkan hasil pengamatan terhadap pelaksanaan proses pembelajaran akuntansi keuangan, diperoleh gambaran aktivitas dan hasil belajar siswa selama kegiatan belajar sebagai berikut :

1. Berdasarkan hasil pengamatan aktivitas siswa pada siklus 2 mengalami peningkatan, sebanyak 20\%. Aktivitas siswa pada siklus 2 sebesar $90 \%$ yaitu berada pada kriteria A ( Sangat baik)

2. Pada pelaksanaan siklus 2 dari jumlah keseluruhan 37 siswa, yang telah tuntas ada sebanyak 33 siswa, yang tidak tuntas sebanyak 3 orang dengan 1 siswa tidak hadir, Dari keterangan di atas, dapat disimpulkan siswa yang telah mencapai KKM sebesar 89, $19 \%$. Dengan nilai rata-rata 84,61 ,

Setelah dilakukan tindakan dan evaluasi dalam bentuk tes uji kompetensi, maka diketahui siswa pada siklus 1 sebesar $61,29 \%$ nilai siswa yang berada diatas KKM sebanyak 89,19\% pada siklus 2 berada diatas nilai KKM, maka sesuai dengan target yang telah ditentukan yaitu $85 \%$ siswa mencapai nilai diatas $\mathrm{KKM}$, penelitian tindakan kelas ini dihentikan pada siklus 2 dengan alasan target telah tercapai.

Berdasarkan kedua siklus yang telah dilaksanakan terlihat adanya peningkatan hasil belajar siswa dengan 
menggunakan model pembelajaran group to group exchange. Dan jumlah siswa yang mendapat nilai diatas KKM yaitu 75 juga semakin meningkat. hal ini dapat dilihat pada grafik hasil evaluasi siklus 1 dan siklus 2, sebagai berikut :

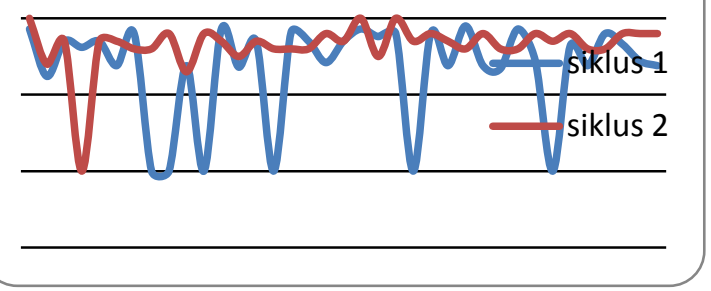

Gb. 1 Perbandingan Hasil Belajar Siklus 1\&2

Sumber : data yang diolah

Berdasarkan grafik diatas dapat dlihat bahwa, pada siklus I dari jumlah 31 siswa yang hadir, siswa yang mendapat nilai diatas KKM sebanyak $61,29 \%$ atau 19 siswa dan $38,71 \%$ atau 12 siswa masih mendapat nilai dibawah KKM. Sedangkan pada siklus 2 dari jumlah 36 siswa yang hadir, siswa yang mendapat nilai diatas KKM sebanyak $89,19 \%$ atau 33 siswa.

Pelaksanaan pada siklus 1 karena siswa masih mengandalkan teman-temannya yang lebih bisa dari dirinya, dan guru kurang memberikan pendekatan kepada siswa-siswa yang kurang aktif dan memberikan apresiasi kepada siswa yang aktif, dan pada siklus 2 guru memperbaikinya dengan cara memberi perhatian dan motivasi kepada seluruh siswa

Nilai rata-rata kelas pada siklus I dan 2 juga mengalami peningkatan, hal ini dapat dilihat dari diagram di bawah ini :

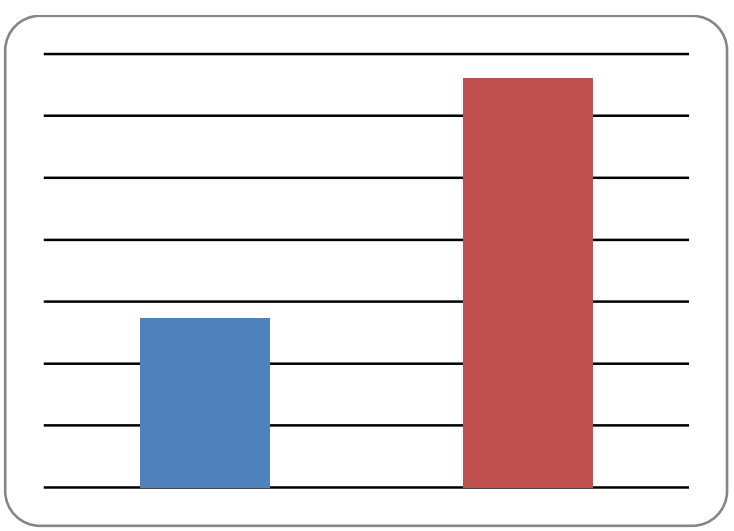

Gb. 2. Nilai Rata-rata Siklus 1 \& 2

Sumber : data yang diolah

Berdasarkan pada diagram diatas, terlihat bahwa ada kenaikan nilai ratarata kelas pada siklus I dan siklus II. Nilai rata-rata siklus I adalah 80,74 sedangkan nilai rata-rata pada siklus II adalah 84,61 . Ini berarti nilai rata-rata dalam kelas pada siklus I dan siklus II mengalami kenaikan sebesar 3,87.

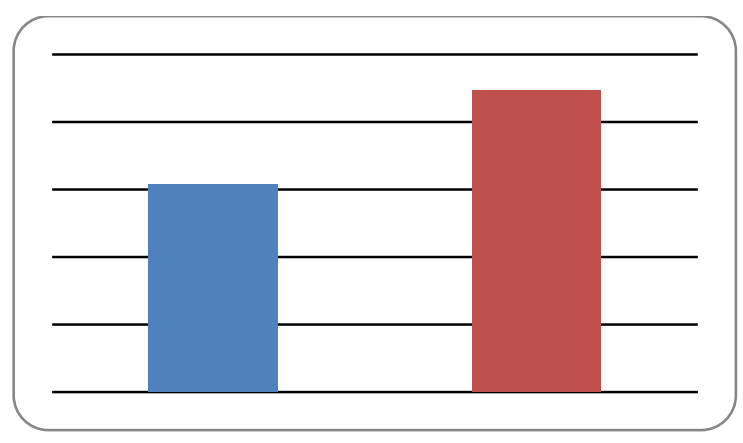

Gb. 3 Ketuntasan Belajar Siswa

Sumber : data yang diolah 
Berdasarkan hasil belajar siswa pada siklus 1 dan siklus 2 telah terlihat adanya peningkatan ketuntasan belajar siswa dengan menggunakan model pembelajaran group to group exchange. Persentase ketuntasan belajar siswa pada siklus 1 yaitu dari 31 orang siswa yang hadir, sebesar $61,29 \%$ atau 19 siswa telah mencapai ketuntasan belajar, sisanya 12 orang siswa belum mencapai ketuntasan belajar. Sedangkan pada siklus 2, dari 36 orang siswa yang hadir, siswa yang mencapai ketuntasan belajar sebesar 89 , 19\% atau 33 siswa telah mencapai ketuntasan belajar, sisanya 3 siswa masih belum mencapai ketuntasan belajar. Dari data tersebut hal ini terbukti hipotesis tindakan bahwa dengan penerapan model pembelajaran group to group exchange dapat meningkatkan hasil belajar siswa kelas XI akuntansi pada mata pelajaran akuntansi keuangan

Setelah kegiatan belajar mengajar dengan menggunakan model pembelajaran group to group exchange, siswa semakin aktif dalam mengikuti pembelajaran di dalam kelas. Hal ini dapat dilihat dalam grafik hasil observasi siswa berikut ini

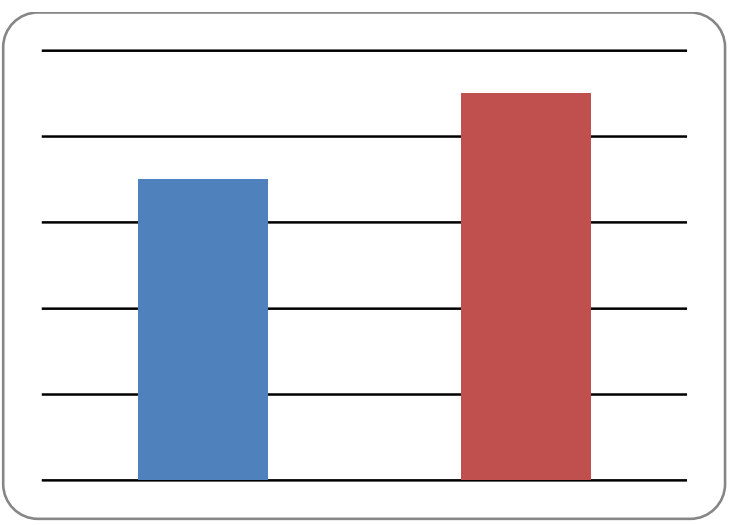

Gb. 4 Hasil Observasi Aktifitas Siswa

Sumber : data yang diolah

Berdasarkan hasil pengamatan, aktivitas siswa mengalami peningkatan, aktivitas siswa pada siklus 1 sebesar $70 \%$ yaitu berada pada kriteria C (Cukup), sedangkan aktivitas pada siklus 2sebesar 90\% yaitu berada pada kriteria A (Sangat Baik). Aktivitas siswa dari siklus I ke siklus II mengalami peningkatan sebesar $20 \%$.

Siswa yang sebelumnya kurang aktif saat pembelajaran, sekarang menjadi lebih antusias dan lebih merespon apersepsi yang diberikan oleh guru. Siswa yang sebelumnya kurang bisa bekerja sama dalam kelompok, pada siklus 2 ini sudah mulai bisa bekerja sama dengan teman kelompoknya dengan baik. Siswa juga jadi lebih berani mengungkapkan pendapatnya kembali di depan teman-temannya. Meskipun begitu, masih diperlukan motivasi dan pendekatan dari guru untuk mendukung 
berhasilnya proses belajar mengajar. Masalah yangdihadapi pada saat proses pembelajaran akuntansi keuangan sudah dapat teratasi dengan cara penerapan model pembelajaran group to group exchange yang secaralangsung dapat meningkatkan aktivitas siswa yang dilihat dari pengamatan atas pelaksanaan, serta dapat meningkatkan hasil belajar siswa.

\section{KESIMPULAN DAN SARAN}

Berdasarkan penelitian tindakan kelas dengan menggunakan model pembelajaran group to group exchange yang dilakukan di SMKN7 Kota Serang dapat disimpulkan bahwa :

1. Penerapan model pembelajaran group to group exchange dapat meningkatkan aktivitas siswa di dalam kelas pada saat kegiatan belajar mengajar. Hasil observasi aktivitas siswa pada siklus 1 sebesar $70 \%$ dan padasiklus II sebesar $90 \%$, terdapat peningkatan sebesar $20 \%$

2. Penerapan model pembelajaran group to group exchange pada mata pelajaran akuntansi keuangan dapat meningkatkan hasil belajar siswa. Pada siklus 1 nilai rata-rata siswa dalam kelas adalah 80,74 sedangkan nilai rata-rata dalam kelas pada siklus II adalah 84,61. Ini berarti nilai rata-rata dalam kelas pada siklus I dan siklus II mengalami kenaikan sebesar3,87. Selanjutnya, dilihat dari persentase ketuntasan belajar siswa, pada siklus I memperoleh $61,29 \%$ meningkat menjadi $89,19 \%$ pada siklus 2 Peningkatan presentase ketuntasan belajar siswa yang diperoleh pada siklus 1 dan siklus 2 sebesar 27, 9\%. Setelah penelitian dilaksanakan, saran yang dapat diberikan peneliti adalah sebagai berikut :

1. Hendaknya siswa dapat selalu aktif serta memiliki antusias menunjukkan partisipasinya dalam mengikuti kegiatan pembelajaran sehingga dapatmenghasilkan pengetahuan yang bersifat komperhensif baik.

2. Siswa hendaknya meningkatkan keterampilan komunikasi yang baik, baik dengan guru maupun siswa, serta meningkatkan rasa percaya diri akan kemampuan yang dimiliki.

3. Diharapkan guru lebih kreatif dalam melakukan inovasi pembelajaran. Berani berinovasi untuk menerapkan dan 
menggunakan model serta media

pembelajaran yang kreatif dan

menarik serta bersifat

menyenangkan

4. Bagi sekolah, perlu menyediakan fasilitas penunjang yang mampu mendukung usaha pelaksanaan pembelajaran yang aktif, kreatif dan menyenangkan.

5. Peneliti lain hendaknya termotivasi untuk melengkapi penelitian ini dengan menggunakan pendekatan lain untuk meningkatkan prestasi belajar khususnya pada mata pelajaran akuntansi keuangan.

\section{DAFTAR PUSTAKA}

Arikunto, Suharsimi (2014) Penelitian Tindakan Kelas .Jakarta: PT Bumi Aksara

Isjoni (2016). Cooperative Learning Mengembangkan KemampuanBelajar Kelompok. Bandung:Alfabeta

$\begin{array}{lrr}\text { Rusman (2011) } & \text { Model-model } \\ \text { Pembelajaran: } & \text { Mengembangkan } \\ \text { Profesionalisme } & \text { Guru. } \\ \text { Jakarta:Rajawali Pers } & & \\ & & \\ \text { Silberman, Melvin } & \text { L } & (2013) \\ \text { ActiveLearning : 101 } & \text { Cara } & \text { Belajar } \\ \text { Siswa Aktif. } & \text { Bandung: } \\ \text { NuansaCendikia } & & \end{array}$

Suprijono,Agus. (2015) Cooperative Learning Teori \& Aplikasi Paikem
Edisi Revisi.Yogyakarta: Pustaka Pelajar 